\title{
20. INTERSTITIAL WATER CHEMISTRY: DEEP SEA DRILLING PROJECT, LEG 10
}

\author{
Bob J. Presley,' Chari Petrowski, and Ian R. Kaplan, Department of Geology and Institute of Geophysics and \\ Planetary Physics, University of California, Los Angeles, California
}

\section{INTRODUCTION AND PROCEDURES}

Only thirteen pore water samples were received at UCLA from the DSDP Leg 10 operations in the Gulf of Mexico. These had been collected at seven different drilling sites, with only one sample from each of four sites and poor vertical coverage at the others. Such sample coverage does not permit an intelligent interpretation of the data.

The 5-ml water samples we received had been forced through a 0.45 micron filter immediately after removal from the sediment and had been stored at $4^{\circ} \mathrm{C}$ in sealed plastic syringes. Analysis was started as soon as the samples were received, which was as long as three months after collection.

The analytical procedures currently being used in our pore water program are essentially those described in some detail elsewhere (Presley, 1971; Presley and Claypool, 1971). These procedures have evolved as we have sought to get more and better data from the small samples provided by the Deep Sea Drilling Project. Therefore, the procedures used for Leg 10 may, in some instances, be modifications of those described in the references, but any changes are not considered sufficiently significant to warrant a separate description here.

\section{RESULTS AND DISCUSSION}

All data that we have obtained to date from the water samples are given in Table 1, except major cation concentrations, which are discussed in the report by Manheim et al. (Chapter 21). The shipboard $\Sigma \mathrm{CO}_{2}$ values which were given in our previous reports have been omitted here, because, as on previous legs, the laboratory and shipboard values show moderately good agreement, and the laboratory values are more reliable.

The chloride and bromide values given in Table 1 were each determined using approximately $0.2 \mathrm{ml}$ of water; there was in no case sufficient sample for replicate determinations. For this reason, variations in the data of less than 2 per cent or so does not warrant speculation as to its cause. Thus, we feel that there is no significance to the fact that nearly all pore water samples seem to be 1 to 2 per cent lower in $\mathrm{Cl}$ and $\mathrm{Br}$ than the overlying Gulf of Mexico bottom water. This is most likely due to an error in calculating the dilution factor used on the samples.

The bottom sample from Site 92 presents a different case, however, because it is enriched in $\mathrm{Cl}$ by more than 5 -fold, yet is near normal in $\mathrm{Br}$ content. This hole was drilled on a diapir structure and salt was expected at about

Present address: Department of Oceanography Texas A\&M University College Station, Texas
300 meters depth. Unfortunately, the hole could not be drilled that deep, but the pore water chemistry clearly indicates that the deepest sample ( $229 \mathrm{~m}$ depth) has been strongly influenced by a nearby salt deposit.

The $\mathrm{Li}$ concentration is also high at the bottom of Site 92 , but, interestingly enough, the $\mathrm{Li} / \mathrm{Cl}$ ratio is about that of normal seawater. Thus, $\mathrm{Li}$ and $\mathrm{Na}$ must have been incorporated into the salt at about their seawater ratio. This conclusion is complicated by the fact that $\mathrm{Li}$ increases with depth have been a common feature of the DSDP pore waters, and, in fact, an approximate twofold increase was found at Site 94 . On the other hand, no Li increase was found at similar depths in Site 95 and the mechanism for the often observed $\mathrm{Li}$ enrichment in the absence of a salinity increase is still not clear.

Boron concentrations in the Leg 10 samples did not differ significantly from those of seawater, which is consistent with most of our previous observations. The bottom sample of Site 92 was depleted in $\mathrm{B}$, giving a $\mathrm{B} / \mathrm{Cl}$ ratio some ten times smaller than that of seawater. Silica was also low in this sample, whereas many of the other samples appear to be nearly saturated with respect to amorphous silica, even in sediment that is predominantly carbonate ooze.

Manganese concentrations show the wide variation that has characterized all of our pore water work, DSDP and otherwise. As usual there is no correlation between $\mathrm{Mn}$ and other measured parameters, and once again there is a good example (Site 94) of a high dissolved Mn concentration near the sediment surface dropping to low values at depth. This pattern is so common that it is hard to see how upward diffusion of $\mathrm{Mn}$, so often proposed as a general phenomenon, can in fact be so.

Ammonia concentrations are generally somewhat lower than we have found in other relatively rapidly deposited sediments, but are still much higher than are found in seawater. The highest concentration was found at Hole 92, in the most clay-rich sediments.

Total dissolved carbonate species concentration is higher than seawater for all samples, with a maximum enrichment of a little over threefold at intermediate depths in Site 94. The carbon isotope ratios show that the added carbon is a result of biological degradation in the sediment column (Presley and Kaplan, 1968). There is, nevertheless, no correlation between the concentrations of $\mathrm{CO}_{2}$ and $\mathrm{NH}_{3}$, in spite of their common source. This is no doubt due to secondary reactions, the most important of which is carbonate precipitation.

\section{ACKNOWLEDGMENTS}

This work was supported in part by AEC Grant AT (11-1)-34 P.A. 134 and NSF Grant GA-20715. 
TABLE 1

Selected Major and Minor Elements, Interstitial Water Deep Sea Drilling Project, Leg 10

\begin{tabular}{|c|c|c|c|c|c|c|c|c|c|c|c|}
\hline $\begin{array}{l}\text { Sample } \\
\text { Number }\end{array}$ & $\begin{array}{c}\text { Depth }^{2} \\
\text { (m) }\end{array}$ & Age and Description of Sediments ${ }^{3}$ & $\begin{array}{c}\mathrm{C1} \\
\mathrm{g} / \mathrm{Kg}\end{array}$ & $\begin{array}{c}\mathrm{Br} \\
\mathrm{mg} / \mathrm{Kg}\end{array}$ & $\begin{array}{c}\text { B } \\
\mathrm{mg} / \mathrm{Kg}\end{array}$ & $\begin{array}{c}\mathrm{Si} \\
\mathrm{mg} / \mathrm{Kg}\end{array}$ & $\begin{array}{c}\mathrm{NH}_{3} \\
\mathrm{mg} / \mathrm{Kg}\end{array}$ & $\begin{array}{c}\mathrm{Mn} \\
\mu \mathrm{g} / \mathrm{Kg}\end{array}$ & $\begin{array}{c}\mathrm{Li} \\
\mu \mathrm{g} / \mathrm{Kg}\end{array}$ & $\begin{array}{c}\Sigma \mathrm{CO}_{2} \\
\mathrm{mM} / \mathrm{Kg}\end{array}$ & $\begin{array}{l}\delta \mathrm{C}^{13} \\
\mathrm{PDB}\end{array}$ \\
\hline $86-1-2$ & 15 & Pleistocene green clayey coccolith ooze & 19.0 & 66 & 5.5 & 8.5 & 1.1 & 2100 & 210 & 3.20 & -1.9 \\
\hline $89-1-3$ & 3 & Pleistocene mottled clayey carbonate ooze & 19.0 & 66 & 5.2 & 11.8 & $<0.2$ & 4800 & 195 & 3.88 & -12.0 \\
\hline $90-1-6$ & 9 & Pleistocene green clayey carbonate ooze & 19.1 & 65 & 5.2 & 8.0 & 4.3 & 3100 & 195 & 5.02 & -14.3 \\
\hline $\begin{array}{l}94-1-2 \\
94-3-4 \\
94-4-3 \\
94-6-4\end{array}$ & $\begin{array}{r}2 \\
105 \\
135 \\
213\end{array}$ & $\begin{array}{l}\text { Pleistocene carbonate ooze } \\
\text { Pliocene carbonate ooze } \\
\text { Pliocene carbonate ooze } \\
\text { Pliocene carbonate ooze }\end{array}$ & $\begin{array}{l}19.0 \\
19.2 \\
19.1 \\
19.0\end{array}$ & $\begin{array}{l}66 \\
66 \\
65 \\
64\end{array}$ & $\begin{array}{l}5.4 \\
5.4 \\
5.5 \\
5.5\end{array}$ & $\begin{array}{l}13.1 \\
20.0 \\
20.1 \\
21.0\end{array}$ & $\begin{array}{r}<0.2 \\
6.8 \\
9.6 \\
8.3\end{array}$ & $\begin{array}{r}1875 \\
<75 \\
<75 \\
<75\end{array}$ & $\begin{array}{l}185 \\
380 \\
360 \\
350\end{array}$ & $\begin{array}{l}3.56 \\
8.30 \\
8.21 \\
6.43\end{array}$ & $\begin{array}{c}-2.9 \\
-10.7 \\
-0.3 \\
0\end{array}$ \\
\hline $\begin{array}{l}95-2-3 \\
95-3-5 \\
95-5-4\end{array}$ & $\begin{array}{r}86 \\
128 \\
203\end{array}$ & $\begin{array}{l}\text { Oligocene carbonate ooze } \\
\text { Oligocene carbonate ooze } \\
\text { Oligocene carbonate ooze/chalk }\end{array}$ & $\begin{array}{l}19.2 \\
19.2 \\
19.2\end{array}$ & $\begin{array}{l}66 \\
66 \\
66\end{array}$ & $\begin{array}{l}- \\
4.4 \\
4.3\end{array}$ & $\begin{array}{l}21.6 \\
24.0 \\
22.1\end{array}$ & $\begin{array}{l}2.4 \\
0.2 \\
1.9\end{array}$ & $\begin{array}{r}100 \\
75 \\
75\end{array}$ & $\begin{array}{l}185 \\
190 \\
190\end{array}$ & $\begin{array}{l}2.88 \\
3.26 \\
3.02\end{array}$ & $\begin{array}{l}-0.4 \\
-0.8 \\
-1.8\end{array}$ \\
\hline
\end{tabular}

${ }^{1}$ Site, cone, section.

${ }^{2}$ Depth below sediment-water interface.

${ }^{3}$ From preliminary site summaries.

\section{REFERENCES}

Presley, B.J. and Kaplan, I.R., 1968. Changes in dissolved sulfate, calcium and carbonate from interstitial water of nearshore sediments. Geochim. Cosmochim. Acta. 32, 1037.

Presley, B.J., 1971. Techniques for analyzing interstitial water samples. Part I: Determination of selected minor and major inorganic constituents. In Winterer, E.L., Riedel, W.R. et al., 1971. Initial Reports of the Deep Sea Drilling Project,
Volume VII. Washington (U.S. Government Printing Office). 1749.

Presley, B.J. and Claypool, G.E., 1971. Techniques for analyzing interstitial water samples. Part II: Determination of total dissolved carbonate and carbon isotope ratios. In Winterer, E.L., Riedel, W.R. et al., 1971. Initial Reports of the Deep Sea Drilling Project, Volume VII. Washington (U.S. Government Printing Office). 1756. 